\title{
Pelatihan Pemasaran Produk Usaha Mikro Kecil Dan Menengah (UMKM) Berbasis Digital di Kecamatan Citeureup
}

\author{
Guruh Herman Was'an', Anita Sariningsih² \\ 1,2STEBIS Bina Mandiri, Kab. Bogor, Jawa Barat, Indonesia \\ guruh@binamandiri.ac.id
}

\begin{abstract}
Abstrak: Inovasi teknologi dalam pemasaran dengan memanfaatkan internet berupa digital marketing atau internet marketing merupakan paradigma yang harus dipahami dalam bisnis saat ini khususnya sektor UMKM. Sektor UMKM berkontribusi terhadap PDRB Kabupaten Bogor mencapai 28,45 persen pada tahun 2018. Kegiatan pengabdian masyarakat berupa pelatihan pemasaran produk UMKM berbasis digital bertujuan untuk mengetahui penggunaan media pemasaran pada UMKM dan meningkatkan pengetahuan serta keterampilan penggunaan teknologi digital bagi para pelaku UMKM di Kecamatan Citeureup. Metode yang digunakan yaitu observasi, interview, kuisioner, pelatihan dan evaluasi kegiatan pelatihan. Hasil observasi, interview, dan kuisioner diketahui masih kurangnya literasi terhadap teknologi digital dalam pemasaran produk karena kurangnya pengetahuan dan keterampilan dalam penggunaan teknologi digital (social medial marketplace). Hasil kegiatan pelatihan dan evaluasi kegiatan pelatihan diketahui meningkatkan pengetahuan serta keterampilan pelaku UMKM dalam memanfaatkan teknologi digital (social medial marketplace) sebagai sarana pemasaran produk untuk meningkatkan penyerapan hasil UMKM. Kegiatan pengabdian masyarakat ini sangat bermanfaat bagi pelaku UMKM di Kecamatan Citeureup untuk meningkatkan daya saing produk UMKM.
\end{abstract}

Kata Kunci: Digital Marketing, UMKM, Sosial Media, Marketplace

Abstract: Technological innovation in marketing by utilizing the internet in the form of digital marketing or internet marketing is a paradigm that must be understood in today's business, especially the MSME sector. The MSME sector contributed to the GDP of Bogor Regency reaching 28.45 percent in 2018. Community service activities in the form of marketing training for digital-based MSME products aim to find out the use of marketing media in MSMEs and increase knowledge and skills in using digital technology for MSME actors in Citeureup District. The methods used are observation, interviews, questionnaires, training and evaluation of training activities. The results of observations, interviews, and questionnaires show that there is still a lack of literacy in digital technology in product marketing due to a lack of knowledge and skills in using digital technology (social media/marketplace). The results of training activities and evaluation of training activities are known to increase the knowledge and skills of MSME actors in utilizing digital technology (social media/marketplace) as a means of product marketing to increase the absorption of MSME results. This community service activity is very useful for MSME actors in Citeureup District to increase the competitiveness of MSME products.

Keywords: Digital Marketing, MSMEs, Social Media, Marketplace

\section{Pendahuluan}

Permana (2017) menyatakan bahwa sektor UMKM memiliki peran yang sangat strategis bagi perekonomian Indonesia karena sektor ini merupakan salah satu sektor ekonomi yang berkontribusi besar bagi pembentukan PDB. Sektor Usaha Mikro Kecil dan Menengah (UMKM) memiliki kontribusi terhadap PDRB Kabupaten Bogor mencapai 28,45 persen pada tahun 2018.

Berdasarkan Gambar 1 diketahui jumlah UMKM di Kabupaten Bogor setiap tahunnya selalu mengalami kenaikkan dimana kenaikkan signifikan terjadi di tahun 2016 sebesar 44 persen dengan rata-rata kenaikkan sebesar 13,25 persen setiap tahunnya. Data tersebut mencerminkan bahwa masih besarnya potensi UMKM di Kabupaten Bogor untuk dikembangkan, 
sejalan dengan program Pemerintah Provinsi Jawa Barat yaitu UMKM Juara dan Wirausaha Juara. Strategi yang dijalankan pemerintah Provinsi Jawa Barat pada program tersebut yaitu meningkatkan penyerapan hasil UMKM, mendorong pertumbuhan wirausaha baru, pengembangan inkubator bisnis di sektor kecamatan dan pengembangan Gadget Mobile App for License (GAMPIL) bagi UMKM. Salah satu tantangan terbesar untuk menjalankan strategi tersebut pada sektor UMKM yaitu masalah strategi pemasaran hasil UMKM untuk meningkatkan daya saing. Kotler \& Keller (2016) menyatakan bahwa pemasaran adalah tentang mendefinisikan dan memenuhi kebutuhan manusia dan sosial.

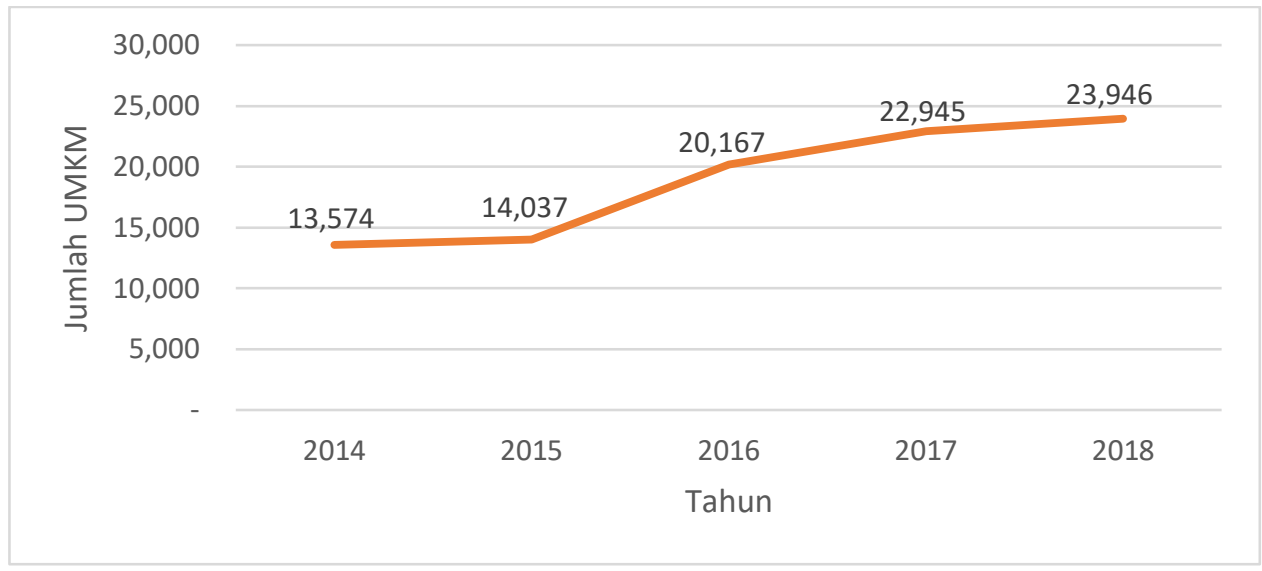

Sumber Dinas Koperasi dan UMKM Kabupaten Bogor, data diolah

Gambar 1. Grafik Jumlah UMKM di Kabupaten Bogor

Beberapa penelitian telah mengungkapan peningkatan daya saing salah satunya dipengaruhi oleh inovasi teknologi. Menurut Anggiani (2018), Inovasi teknologi merupakan inovasi yang dilakukan oleh pelaku usaha dengan menyesuaikan terhadap adanya perubahan teknologi yang terjadi dalam lingkungan bisnis. Penelitian Paulus \& Wardhani (2018) dan penelitian Muthaher \& Assegaf (2014) menyatakan bahwa ada pengaruh signifikan antara variabel inovasi teknologi terhadap keunggulan bersaing. Inovasi teknologi dalam pemasaran dengan memanfaatkan internet berupa digital marketing atau internet marketing merupakan paradigma yang harus dipahami dalam bisnis saat ini. Jika dahulu model interaksi bisnis tradisional bersifat face to face, maka saat ini model interaksi itu telah berkembang ke arah interaksi modern berbasis elektronik atau e-commerce yang faceless. Menurut Taiminen dan Karjaluota (2015), digital marketing bukan hanya tentang memahami teknologi mendasarinya, melainkan tentang memahami orang, bagaimana menggunakan teknologi itu serta memanfaatkan teknologi untuk terlibat secara efektif. Menurut Alford \& Oage (2015) menyatakan bahwa UKM tidak mengikuti perkembangan teknologi digital, khususnya karena kurangnya wawasan tentang pemasaran digital. Wardhana (2015) menyatakan bahwa strategi digital marketing berpengaruh hingga $78 \%$ terhadap keunggulan bersaing UMKM dalam memasarkan produknya. Namun menurut menurut Prayitno \& Safitri (2015) dan Kautsarina (2013) menyatakan bahwa UKM harus cermat dan teliti dalam memilih media sosial yang sesuai dengan tujuan pemasaran 
produknya.

Berdasarkan fenomena yang telah dijelaskan maka penulis terdorong untuk mengetahui lebih dalam dan mencoba untuk melakukan pengabdian masyarakat berbasis riset dengan objek dan tempat yang berbeda. Oleh sebab itu, penulis tertarik untuk melakukan pengabdian masyarakat yang berjudul "Pelatihan Pemasaran Produk UMKM Berbasis Digital di Kecamatan Citeureup".

\section{Metode}

Pengabdian masyarakat yang dilakukan dalam bentuk pelatihan pemasaran berbasis digital yang meliputi identifikasi penggunaan media pemasaran pada UMKM di Kecamatan Citeureup, kegiatan pelatihan pemasaran produk UMKM berbasis digital di Kecamatan Citeureup, dan evaluasi kegiatan. Sasaran kegiatan ini yaitu para pelaku UMKM di wilayah Kecamatan Citeureup Kabupaten Bogor.

1. Metode yang digunakan dalam melakukan identifikasi penggunaan media pemasaran pada UMKM di Kecamatan Citeureup sebagai berikut:

a. Observasi

Kegiatan observasi dilakukan pada beberapa UMKM di Kecamatan Citeureup untuk mengetahui cara dan media yang digunakan UMKM dalam memasarkan produknya.

b. Interview dan kuisioner

Interview dan pemberian kuisioner dilakukan pada beberapa pelaku UMKM di Kecamatan Citeureup untuk mengetahui media pemasaran dan informasi secara kualitatif permasalahan pelaku UMKM dalam memasarkan produknya.

2. Setelah melakukan identifikasi penggunaan media pemasaran pada UMKM di Kecamatan Citeureup, selanjutnya penulis melakukan kegiatan pelatihan pemasaran produk UMKM berbasis digital di Kecamatan Citeureup sebagai berikut:

a. Materi Pendidikan Masyarakat

Pendidikan masyarakat ini bertujuan untuk meningkatkan wawasan serta pengetahuan pelaku UMKM mengenai kewirausahaan dan digital marketing. Selain itu, materi ini dilakukan untuk memberikan motivasi kepada para pelaku UMKM di Kecamatan Citeureup.

b. Pelatihan

Pelatihan ini dilakukan dengan praktek mendaftarkan usaha ke Grabfood, Gofood, Bukalapak, Tokopedia, dan Shopee. Materi ini dilakukan sesuai dengan identifikasi awal dengan para pelaku UMKM di Kecamatan Citeureup.

3. Evaluasi kegiatan

Evaluasi kegiatan dilakukan untuk mengetahui feedback dari para pelaku UMKM berupa tanggapan dan tindaklanjut yang akan dilakukan oleh para pelaku UMKM. Bentuk evaluasi kegiatan ini dilakukan dengan cara penyebaran kuisioner. 


\section{Hasil dan Pembahasan}

Berdasarkan tabel 1, diketahui seluruh peserta UMKM telah memiliki infrastruktur (handphone/ laptop) yang menunjang untuk melakukan pemasaran berbasis digital namun berdasarkan hasil identifikasi tidak seluruh pelaku UMKM yang mengikuti pelatihan menggunakan media sosial atau marketplace dalam memasarkan produknya. Sebanyak 20 dari 24 peserta (83\%) yang memanfaatkan teknologi digital dalam memasarkan produk UMKM dan sebanyak 4 peserta atau $17 \%$ hanya melakukan pemasaran secara tradisional/ offline. Dari 20 peserta UMKM yang menggunakan media sosial atau marketplace dalam memasarkan produknya hanya 8 peserta atau $33 \%$ yang sudah memanfaatkan marketplace.

Tabel 1. Hasil Identifikasi Penggunaan Media Pemasaran pada Peserta Pelatihan UMKM di Kecamatan Citeureup

\begin{tabular}{|c|c|c|c|}
\hline \multirow{2}{*}{ No } & \multirow{2}{*}{ Indikator Penggunaan Media Pemasaran Berbasis Digital } & \multicolumn{2}{|c|}{ Total Peserta } \\
\hline & & $\mathbf{Y a}$ & Tidak \\
\hline 1 & $\begin{array}{l}\text { Kepemilikan Laptop/ Handphone yang menunjang pemasaran } \\
\text { berbasis digital }\end{array}$ & 24 & - \\
\hline 2 & $\begin{array}{l}\text { Penggunaan marketplace } \\
\text { (Bukalapak/Tokopedia/Shopee/Gofood/Grabfood/lainnya) atau media } \\
\text { sosial (WA/ Facebook) dalam pemasaran produk }\end{array}$ & 20 & 4 \\
\hline 3 & $\begin{array}{l}\text { Hanya menggunakan media sosial (WhatsApp/Facebook) dalam } \\
\text { pemasaran produk }\end{array}$ & 12 & 16 \\
\hline 4 & $\begin{array}{l}\text { Penggunaan hanya } 1 \text { marketplace } \\
\text { (Bukalapak/Tokopedia/Shopee/Gofood/Grabfood/lainnya) dalam } \\
\text { pemasaran produk }\end{array}$ & 5 & 19 \\
\hline 5 & $\begin{array}{l}\text { Penggunaan } 2 \text { marketplace } \\
\text { (Bukalapak/Tokopedia/Shopee/Gofood/Grabfood/lainnya) dalam } \\
\text { pemasaran produk }\end{array}$ & 2 & 21 \\
\hline 6 & $\begin{array}{l}\text { Penggunaan } 3 \text { marketplace } \\
\text { (Bukalapak/Tokopedia/Shopee/Gofood/Grabfood/lainnya) dalam } \\
\text { pemasaran produk }\end{array}$ & 1 & 23 \\
\hline 7 & $\begin{array}{l}\text { Penggunaan lebih dari } 3 \text { marketplace } \\
\text { (Bukalapak/Tokopedia/Shopee/Gofood/Grabfood/lainnya) dalam } \\
\text { pemasaran produk }\end{array}$ & - & 23 \\
\hline
\end{tabular}

Berdasarkan hasil identifikasi tersebut diketahui masih kurangnya literasi digital kepada para pelaku UMKM di Kecamatan Citeureup. Hal ini sesuai dengan hasil interview dan kuisioner kepada peserta yang belum memanfaatkan teknologi digital ataupun hanya menggunakan media sosial (WhatsApp/ Facebook) dalam memasarkan produknya dikarenakan kurangnya pengetahuan atas penggunaan marketplace/ media sosial tersebut.

Berdasarkan hasil identifikasi penggunaan media pemasaran dalam memasarkan produk UMKM di Kecamatan Citeureup, maka diperlukan upaya-upaya yang bertujuan meningkatkan pengetahuan serta keterampilan bagi para pelaku UMKM di Kecamatan Citeureup, khususnya mengenai pemasaran berbasis teknologi digital. Dilaksanakannya kegiatan pelatihan pemasaran 
produk UMKM berbasis digital diharapkan mampu menjadi motivasi dan solusi dengan memanfaatkan teknologi digital bagi para pelaku UMKM di Kecamatan Citeureup.

Tabel 2. Hasil Evaluasi dari Peserta Pelatihan UMKM di Kecamatan Citeureup terhadap Kegiatan Pelatihan

\begin{tabular}{|c|c|c|c|c|c|c|}
\hline \multirow[b]{2}{*}{ No } & \multirow[b]{2}{*}{$\begin{array}{c}\text { Indikator Evaluasi dari Peserta } \\
\text { UMKM Terhadap Kegiatan } \\
\text { Pelatihan }\end{array}$} & \multicolumn{5}{|c|}{ Total Peserta } \\
\hline & & $\begin{array}{l}\text { Sangat } \\
\text { Setuju }\end{array}$ & Setuju & $\begin{array}{l}\text { Ragu- } \\
\text { ragu }\end{array}$ & $\begin{array}{l}\text { Tidak } \\
\text { Setuju }\end{array}$ & $\begin{array}{l}\text { Sangat } \\
\text { Tidak } \\
\text { Setuju }\end{array}$ \\
\hline 1 & $\begin{array}{l}\text { Pelatihan memberikan wawasan } \\
\text { khususnya terkait kewirausahaan dan } \\
\text { pemasaran melalui teknologi digital. }\end{array}$ & 21 & 3 & - & - & - \\
\hline 2 & $\begin{array}{l}\text { Pelatihan memberikan motivasi dalam } \\
\text { menjalankan usaha. }\end{array}$ & 19 & 5 & - & - & - \\
\hline 3 & $\begin{array}{l}\text { Materi yang disampaikan dalam } \\
\text { pelatihan akan dipraktekkan dalam } \\
\text { kegiatan usaha. }\end{array}$ & 21 & 3 & - & - & - \\
\hline
\end{tabular}

Berdasarkan tabel 2, diketahui seluruh peserta kegiatan memberikan feedback yang positif terhadap kegiatan pelatihan ini. Sebanyak 21 peserta atau $87,5 \%$ sangat setuju pelatihan memberikan wawasan kewirausahaan dan pemasaran melalui teknologi digital serta materi yang disampaikan dalam pelatihan akan dipraktekkan dalam kegiatan usaha. Sebanyak 19 peserta atau $70,17 \%$ sangat setuju pelatihan memberikan motivasi dalam menjalankan usaha. Berdasarkan hasil evaluasi tersebut diketahui hasil pengabdian mampu mengatasi atau mereduksi permasalahan yang telah diidentifikasi sebelumnya dalam hal pemanfaatan teknologi digital pada pemasaran produk UMKM di Kecamatan Citeureup.

Kesimpulan (Tahoma, 11 pt, Bold)

Berdasarkan hasil identifikasi penggunaan media pemasaran diketahui bahwa masih rendahnya literasi teknologi digital dalam pemanfaatan pemasaran produk UMKM di Kecamatan Citeureup. Hasil dari evaluasi kegiatan pelatihan pemasaran produk UMKM berbasis digital mampu meningkatkan pengetahuan dan keterampilan pelaku UMKM dalam memanfaatkan teknologi digital sebagai sarana pemasaran produk UMKM di Kecamatan Citeureup.

Diharapkan adanya keberlanjutan dari kegiatan pengembangan UMKM di Kecamatan Citeureup. Hasil identifikasi dan evaluasi kegiatan dapat menjadi referensi bagi pihak-pihak lain yang akan melakukan kegiatan pengembangan UMKM di Kecamatan Citeureup. Kegiatan pengembangan UMKM di Kecamatan Citeureup dapat dilakukan seperti pelatihan pencatatan keuangan, pelatihan mendapatkan izin usaha dan kehalalan produk, dan pelatihan transaksi usaha syariah.

\section{Ucapan Terima Kasih}

Terima kasih yang sebesar-besarnya kepada pihak STEBIS BINA MANDIRI dan masyarakat Kecamatan Citeureup atas bantuan, kerjasama, serta dukungannya sehingga 
kegiatan pelatihan berjalan baik. Terima kasih juga kepada tim mahasiswa Program Kreativitas Mahasiswa (PKM) Prodi Akuntansi STEBIS BINA MANDIRI Tahun 2020 di Kecamatan Citeureup.

\section{Referensi}

Alford, P \& Page, S.J (2015) Marketing technology for adoption by small business. The Service Industries Journal, 2015 Vol. 35, Nos. 11-12, 655-669

Anggiani. S. (2018). Kewirausahaan: Pola Pikir, Pengetahuan, Keterampilan. Jakarta: Prenadamedia Group

Kautsarina. (2013). Pemasaran Elektronik Melalui Aplikasi Jejaring Sosial. Jurnal Studi Komunikasi dan Media. 17(2). 135-148.

Kotler, P., \& Keller, K. L. (2016). Marketing Management (15th ed.). Harlow: Pearson Education Limited.

Muthaher, O., \& Assegaf, M. (2014). Model Pengembangan Inovasi Teknologi Dan Kelembagaan Kemitraan Rantai Pasok Guna Meningkatkan Daya Saing UKM. EKOBIS, 62-73.

Paulus, L. B., \& Wardhani, Z. K. (2018). Keunggulan Bersaing Usaha Cake Dan Bakery: Peran Orientasi Pasar, Orientasi Kewirausahaan, dan Inovasi Produk. Jurnal Manajemen, 10(2), 8896

Permana, S.H. (2017) Strategi Peningkatan Usaha Mikro, Kecil dan Menengah (UMKM) di Indonesia. Aspirasi, 8 (1), Juni 2017

Prayitno, Agus. Yulia Safitri. 2015. Pemanfaatan Sistem Informasi Perpustakaan Digital Berbasis Website Untuk Para Penulis. Volume 1 No 1-2015. ISSN: 2461-0690

Taiminen, H., \& Karjaluoto, H. (2015). The usage of digital marketing channels in SMEs. Journal of Small Business and Enterprise Development, 22 (4), 633-651.

Wardhana, A. (2015). Strategi Digital Marketing dan Implikasinya pada Keunggulan Bersaing UKM di Indonesia. Seminar Nasional Keuangan dan Bisnis IV UPI, 327-337. 